\title{
Petrophysical analysis of well logs data for identification and characterization of the main reservoir of AI Baraka Oil Field, Komombo Basin, Upper Egypt
}

\author{
Ahmed H. Senosy ${ }^{1}$ (D) Hatem F. Ewida ${ }^{2} \cdot$ Hassan A. Soliman $^{3} \cdot$ Mohamed O. Ebraheem $^{1}$
}

Received: 3 March 2020 / Accepted: 16 June 2020 / Published online: 27 June 2020

(c) Springer Nature Switzerland AG 2020

\begin{abstract}
The current study presents the log analysis results from two vertical onshore wells in Al Baraka oil Field, Komombo basin, upper Egypt. The Geophysical logs comprising gamma ray (GR), caliper (Cali), resistivity (LLD, LLS, and MSFL), photoelectric effect (PEE), neutron (NHPH) and density (RHOB) are used to study the petrophysical characteristics of the main identified reservoirs in this field. The key purpose of well logging analysis and interpretation is to obtain petrophysical properties of reservoirs such as shale volume, porosity, hydrocarbon saturation, net pay thickness, etc., for hydrocarbon exploration. Petrophysical analysis of well logs reveals that Al Baraka wells consist of three types of lithology: sand, shale, and siltstone. The obtained results show that there are two hydrocarbon-bearing zones named (S-E) and (S-D) zone for Al Baraka-4 well and Al Baraka-14 well, respectively; both had hydrocarbon reservoir bearing oil and lie in Six Hills Fm of the Lower Cretaceous. The generated cross-plots showed that the main reservoir lithology is composed of shaley sandstone to sandstone. The computed petrophysical parameters for the identified and characterized reservoir layers reveal that they have a total porosity range of $18.2-20.1 \%$, water saturation of $57.7-36.6 \%$, shale volume of $20-8.5 \%$ for (S-E) and (S-D) zone, respectively. The hydrocarbon saturation reaches to $42.5 \%$ for (S-E) zone and $36.6 \%$ for (S-E) zone; both hydrocarbons in these zones are movable. The net reservoir pay thickness is high in (S-E) zone reach to $24 \mathrm{ft}$. Below and above the oil-bearing reservoirs, there is a thick shale bed which acts as potential source rock or as a seal rock. The overall results indicated that the sandy reservoir units of 'Al Baraka' Field have the potential to contain significant accumulations of hydrocarbon, essential oil. It is recommended to integrate more wells and seismic data to better evaluate the reservoirs.
\end{abstract}

Keywords Reservoir · Petrophysical parameters · Well log analysis · Hydrocarbon-bearing zones Komombo basin

\section{Introduction}

Petrophysical analysis of well logs is one of the most useful and important tools for reservoir rock characterization. The productivity of wells in hydrocarbon-bearing reservoirs depends on petrophysical properties which include lithology, porosity, water saturation, permeability, and saturation [1]. Generally, the petrophysics framework here is termed as formation evaluation, which is the process of using borehole measurements to evaluate the characteristics of subsurface formations [2]. Well logs data, such as gamma ray, density, neutron porosity log, photoelectric effect values, and resistivity (LLD, LLS, and MSFL) logs, were used to achieve this task. The proposed study aims to interpret the well logs data and quantitatively evaluate the petrophysical properties to identify promising zones for hydrocarbon accumulation with depth and thickness

\footnotetext{
$\triangle$ Ahmed H. Senosy, ahmed.s@scinv.au.edu.eg|'Department of Geology, Faculty of Science, New Valley University, Al-Kharga 72511, New Valley, Egypt. ${ }^{2}$ North Sinai Petroleum Company (NOSPCO), New Maadi, Maadi, Cairo 11931, Egypt. ${ }^{3}$ Geology Department, Faculty of Science, Assiut University, Assiut, Egypt.
} 
of these zones and to distinguish the interfaces of oil, gas, or water in parts of Al Baraka oil filed.

Based on the history of petroleum exploration and production in Egypt, most of the hydrocarbon fields concentrated in three main regions: the Gulf of Suez, the NorthWestern Desert, and the Nile Delta. Southern Egypt has only attracted separate interest since 1990 with success finally arriving by drilling within Komombo concession. In 2007, drilling of the Al Baraka-1 well was a success, and there was establishment of the Al Baraka Field by Dana Gas Company [3]. Komombo Basin is an extensional rift basin, which covers an area of $186 \mathrm{~km}^{2}$ in the southwestern Desert of Egypt [4] Fig. 1a. Komombo basin is filled with a Cretaceous-Cenozoic sedimentary sequence, which is underlain by the Pre-Cambrian basement rock. This succession is approximately reaches $4 \mathrm{~km}$ thick in the deepest parts (depocenter area) [5]. The topography of the Komombo area, which lies west of Faris village and northwest of Aswan city, is relatively gentle to the almost flat desert with no indications of the oil and gas activities Fig. 3.

Al Baraka oil field is present in the eastern part of Komombo Basin Fig. 1a, b. This field is located in the southwestern Desert of Egypt north of Aswan city and covering area of $50 \mathrm{~km}^{2}$, which is currently producing heavy oil from sandstone reservoirs. The main oil field, where most of Al-Baraka wells were drilled, is located approximately $12 \mathrm{~km}$ West of Faris village Fig. 3. The oil of the Al Baraka field is believed to be generated from potential lacustrine shales (high thermal maturity and rich TOC\%) containing mixed terrigenous and marine organic matter, which was deposited in a moderately oxidizing sedimentary environment [3].

\section{Location map and geological setting}

Al Baraka oil field occupies the eastern part of the Komombo basin. It is located $800 \mathrm{~km}$ south of Cairo and lies between latitudes $24^{\circ} 38^{\prime}$ and $24^{\circ} 40^{\prime} 30^{\prime \prime} \mathrm{N}$, and longitudes $32^{\circ} 46^{\prime}$ and $32^{\circ} 50^{\prime} 30^{\prime \prime}$ E [6] Fig. $1 \mathrm{~b}$.

\subsection{Location map of the study area}

The study area is located in the south of Egypt in the eastern part of the Komombo basin, where the discovered
Fig. 1 a Komombo concession index map in Upper Egypt; b map showing the location of the Al Baraka oil field in Komombo Basin [4]

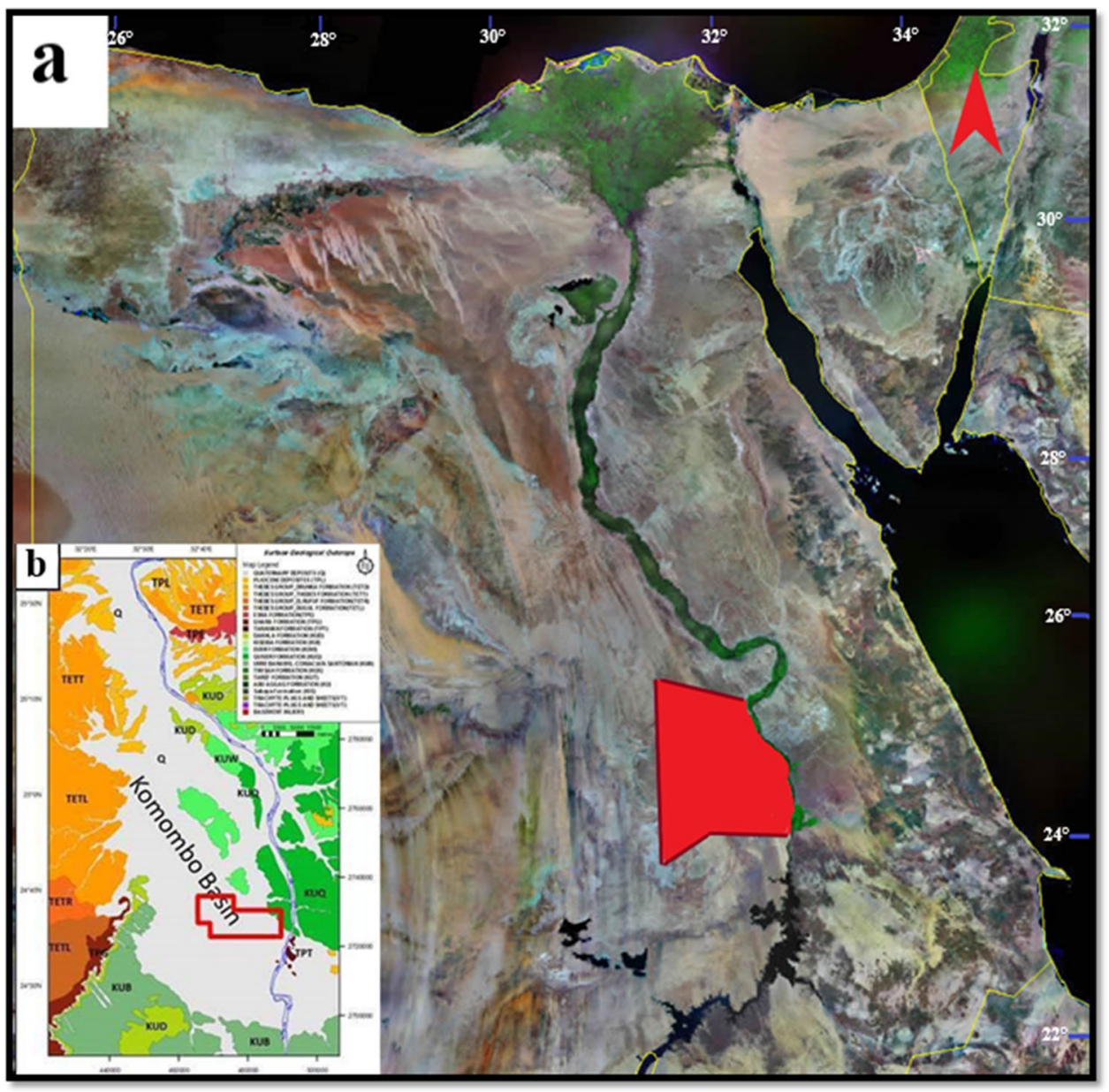


Al Baraka oil field is present. This field includes two wells named Al Baraka-14 (Cg 78-14) and Al Baraka-4 (Cg 78-4). Figures 2 and 3.

\subsection{Regional geological setting}

Komombo basin is a half-graben system filled with thick non-marine sediments deposited during Early Cretaceous (Hauterivian to Barremian) followed by marine deposition during Albian/Cenomanian (argillaceous sandstones and shales) and later shales and marine limestones during Late
Cretaceous and early Tertiary [7]. Stratigraphic boundaries and lithostratigraphic sequences are based on wireline logs lithofacies description, microscopic examination of ditch cutting samples for drilled wells, and biostratigraphic analysis. The stratigraphic sequences of the komombo basin are characterized by two major sedimentary breaks (non-deposition or erosional phases), represented by the gap in time between the Pre-Cambrian Basement rock and the Neocomian sediments and between the Cretaceous sequence and the overlying Paleocene sediments due to the regional uplift event on the area. Also, this

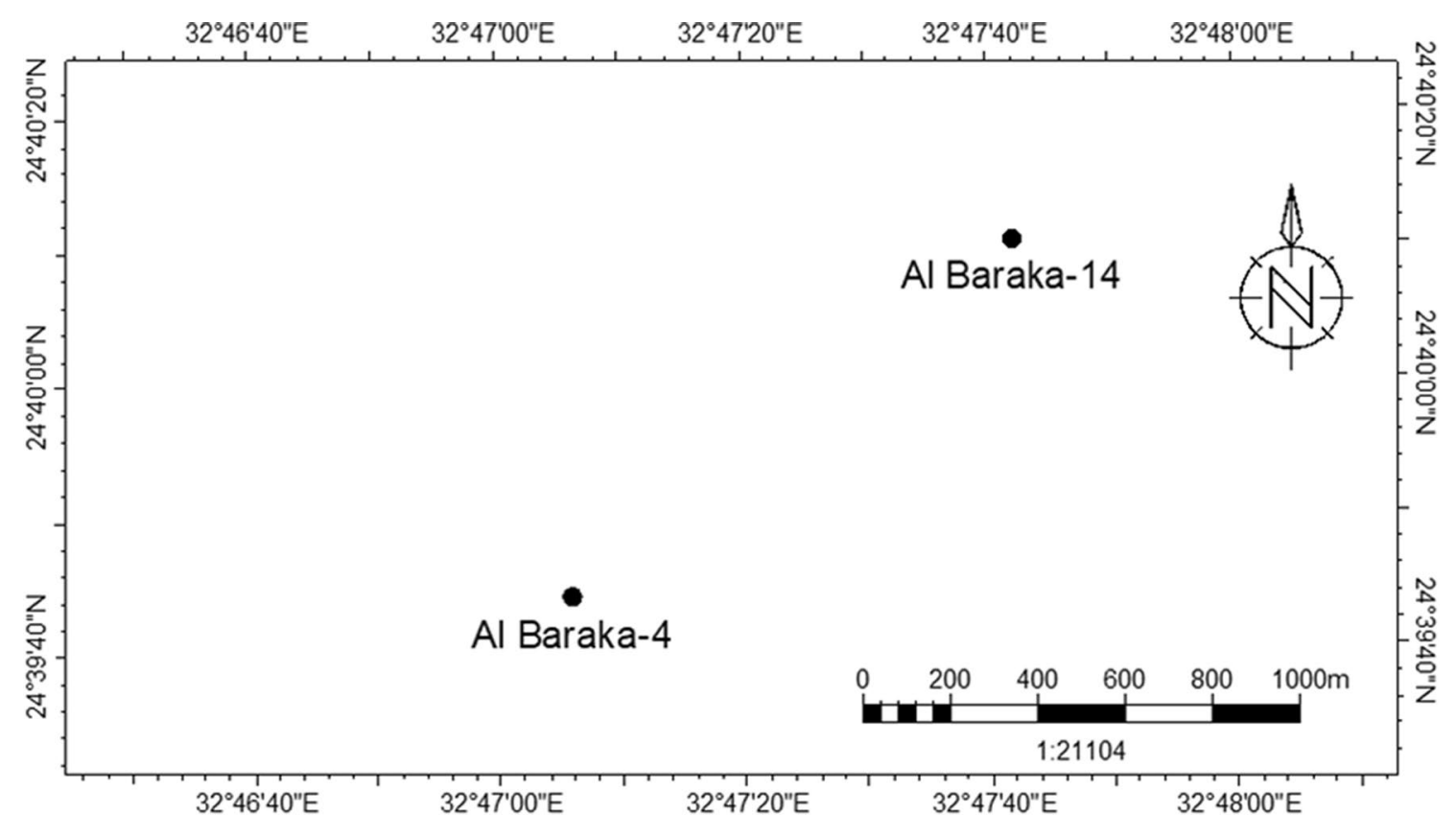

Fig. 2 Location map of the two studied wells

Fig. 3 Google earth image showing the location of the study area in Al-Baraka field with respect to the Faris Village

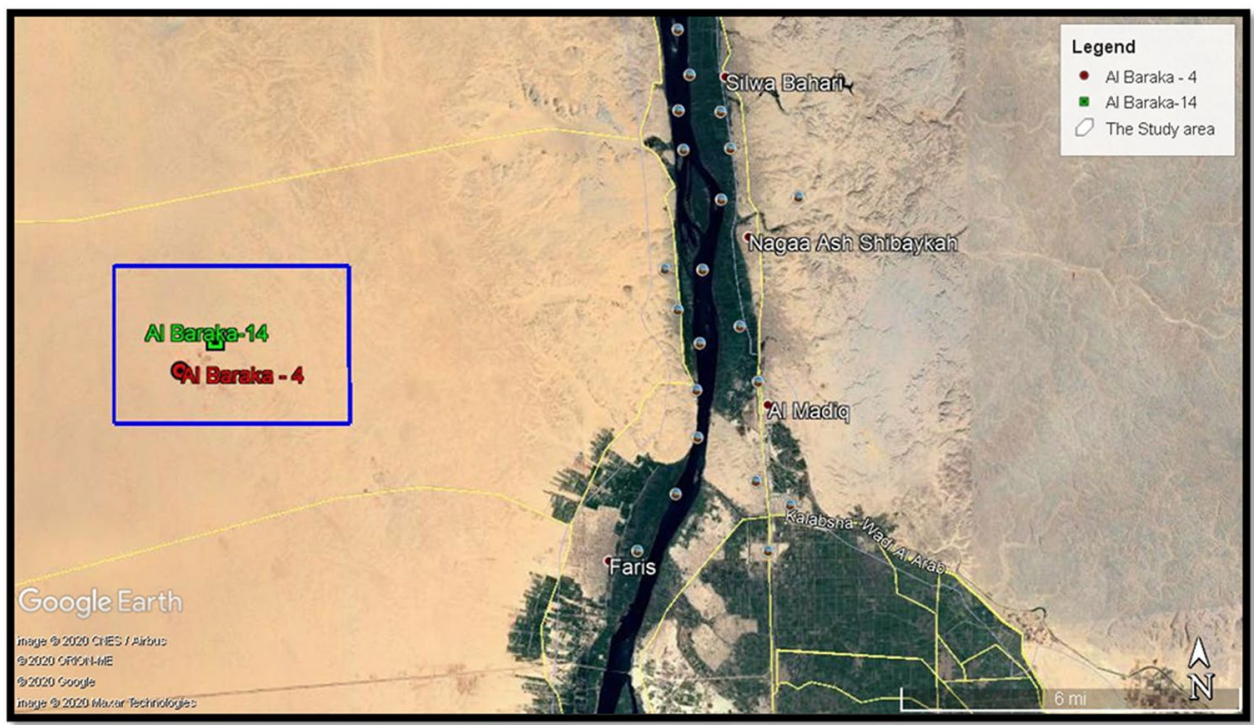

SN Applied Sciences A SPRINGER NATURE journal 
sequence has two minor inter-formational stratigraphic gaps; hiatus were detected between Neocomian and Barremian around three million years, and between Aptian and Albian sequences of around fourteen million years [8].

Sedimentation effectively terminated in the upper cretaceous (Santonian/Campanian) simultaneous with the earliest development of the Red Sea which bounds the eastern side of the Western Desert basin.

The Cretaceous succession in the Komombo basin Concession as shown in Fig. 4 generally consists of six formations from top to the base: Dakhla, Quseir, Taref, Maghrabi, Sabaya, Abu Ballas, Six Hills formation [9]. Six Hills formation is subdivided into seven members from base to top (A-G); also it provides the main source rock which is dark shale rich in an organic matter especially in $B$ member of Six Hills formation [8] Fig. 4.

The primary targets for hydrocarbon exploration in North and Central Africa are the Mesozoic Rift basins [10, 11]. In the southwestern Desert of Egypt Bouguer gravity and aeromagnetic data show large elongated structural lows, grabens, and half-grabens $[6,12]$. The Komombo Basin is considered an extensional rift basin, which appears to be a half-graben [13] Fig. 5, probably developed in an extensional stress regime originated in Central and North Africa with the opening of South Atlantic, which is started from the Late Jurassic-Early Cretaceous age and terminated in the Late Cretaceous by the Syrian Arc inversion in southern Egypt [14]. This rift basin is filled with sedimentary sequences that reach $4 \mathrm{~km}$ thick ranging from non-marine lacustrine facies to fully marine systems Fig. 4. The main bounding fault of the Komombo Basin is located to the northeast and trending NW-SE, while the subordinate faults are mainly synthetic and of the same trend $[6,13]$ Fig. 5.

\section{Materials and methods}

Understanding and knowing the subsurface comes primarily from drilling, which is a very expensive process. Wireline logging offers an opportunity to determine the composition, variability and physical properties of the rocks around the well, thereby enabling a proper good method for the understanding of subsurface at a cheaper cost.

\subsection{Available data}

The Wireline logs data for this study were collected from Ganoub El Wadi Petroleum Holding Company. The available drilled boreholes are Al Baraka-4 and Al Baraka-14, each well has main logs like gamma ray (GR), spontaneous potential(SP), caliper (CL), density(RHOB), neutron

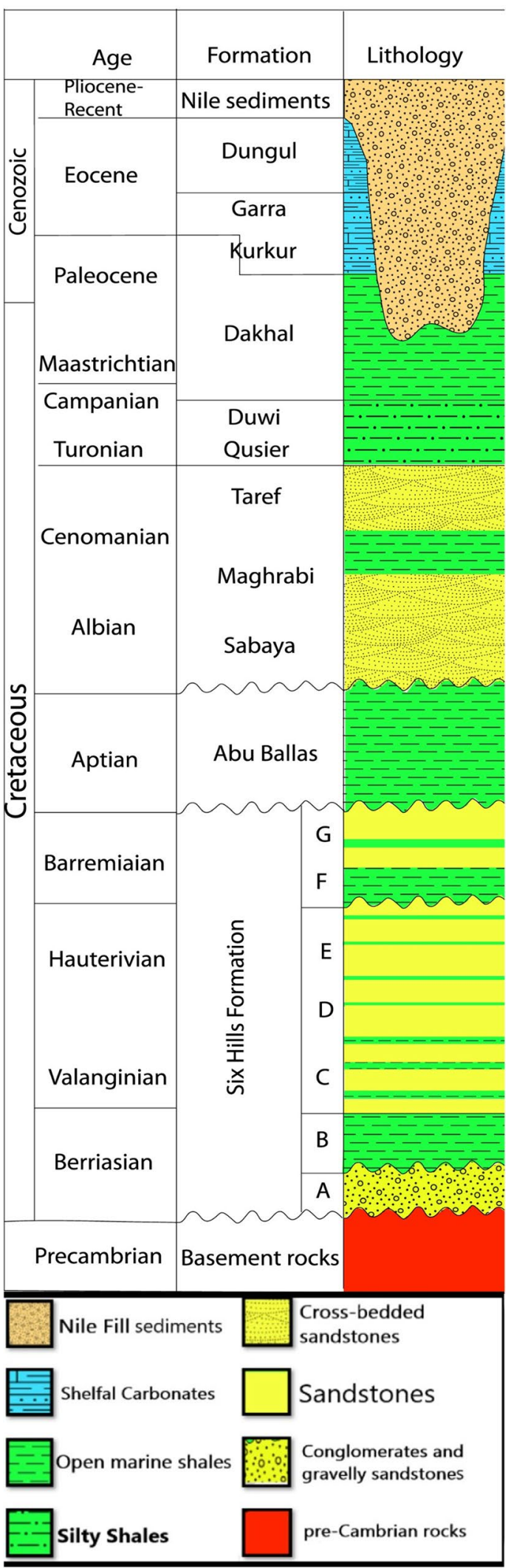

Fig. 4 Stratigraphic column of Komombo Basin, upper Egypt (modified) [9]

\section{SN Applied Sciences}




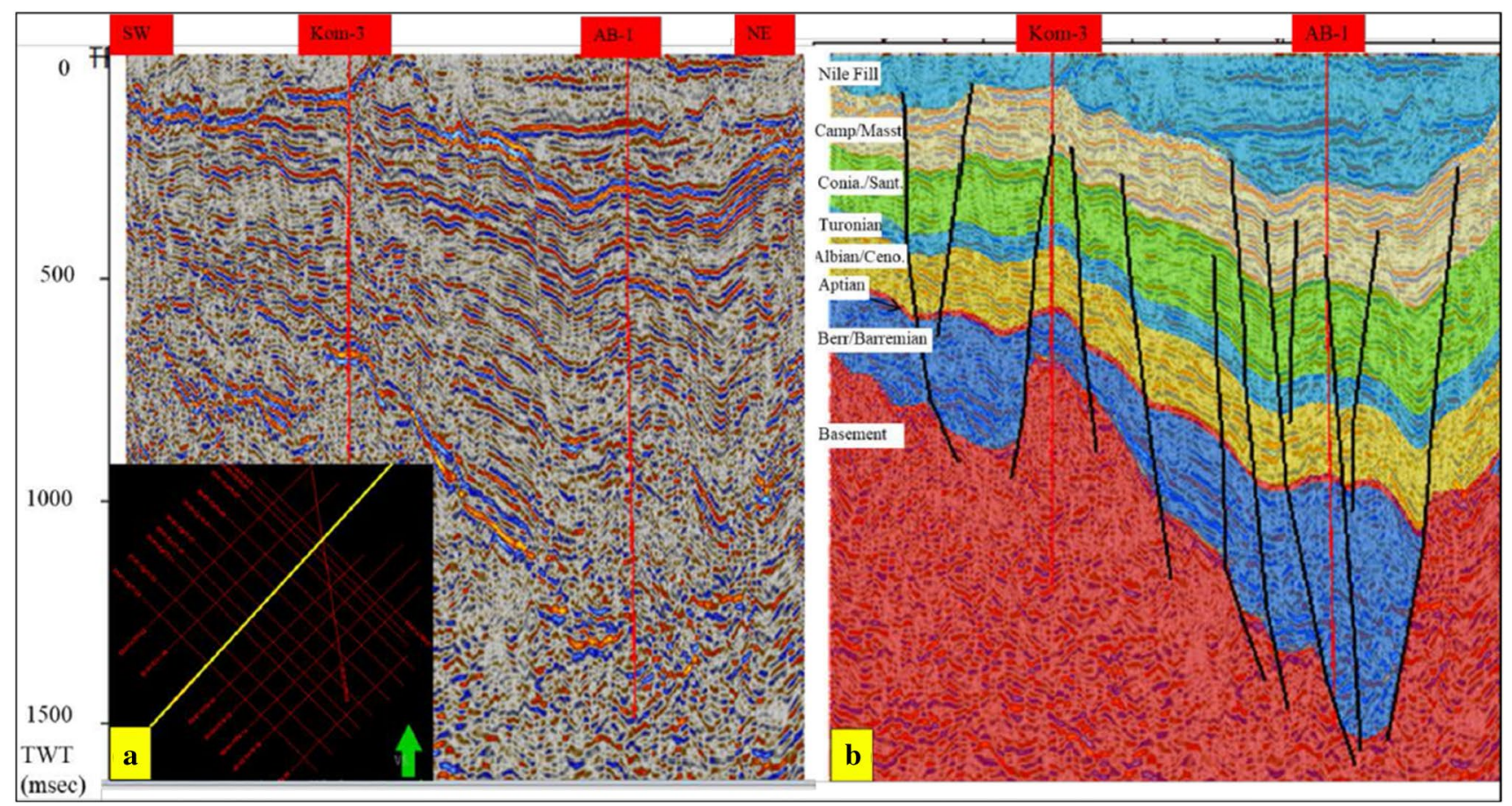

Fig. 5 a Un-interpreted NE-SW 2D seismic section (05-01-Cf 77-08) crossing the Komombo basin, Upper Egypt. b Interpreted NE-SW 2D seismic section showing the half-graben basin and the main seismic horizons in the study area [13]

(NPHI), photoelectric effect (PEE), resistivity logs [deep resistivity (LLD), shallow resistivity (LLS), medium resistivity (LLM)]. These logs are used for calculating the petrophysical parameters as no core data is available; these logs are delivered as soft copies (Las files (as shown in Table 1. The Techlog version 2015.1 and Petrel version 2015.5 software was used to integrate all the available data to interpret and compute the input of the different petrophysical properties to deliver a more realistic and accurate formation evaluation.

\subsection{Methods}

Generally, the wireline logs like GR, SP, and caliper logs were used for the correlation of depth and identification of permeable zones in addition to identifying the same facies in the wells, which have a lack of core data. Porosity logs as (density logs, neutron logs, sonic logs) were used to calculate porosity at each point. Resistivity logs were used to obtain water saturation. After obtaining water saturation, both oil and gas saturation can be calculated.

The procedure for calculation of petrophysical parameters are as follows:

\subsubsection{Lithology determination}

The lithology identification is pivotal for reservoir characterization because all of the Petrophysical parameters, such as porosity and permeability depend on facies type. Besides, fluid saturations directly depend on facies types [15]. In this study, lithology across Al Baraka wells was identified by using gamma ray (GR) log, photoelectric factors (PEF) Table 2. Cross-plots are used to define lithology and petrophysical parameters using different types of logs. Neutron-density-gamma ray and also density-photoelectric effect-gamma ray cross-plots indicate lithology and porosity of the formation [1].

Table 1 The available open hole wireline logs and [surface temperature (ST), bottom hole temperature (BHT)] for the two studied wells

\begin{tabular}{llll}
\hline Well name & Available well logs & ST (DegF) & BHT (DegF) \\
\hline Al Baraka-4 & GR, Caliper, BSZ, SP, RHOB, NPHI, PE, LLS, LLD and MSFL & 80 & 160 \\
Al Baraka-14 & & 65 & 165 \\
\hline
\end{tabular}


Table 2 Photoelectric parameters for common lithology in sedimentary rock [16]

\begin{tabular}{llllll}
\hline Lithology & Sandstone & Dolomite & Shale & Limestone & Anhydrite \\
\hline $\begin{array}{l}\text { PEF value } \\
\text { barns/ } \\
\text { electron }\end{array}$ & $1.8-2$ & $3.14-4$ & $1.8-6$ & 5 & 5 \\
\hline
\end{tabular}

\subsubsection{Reservoir identification}

The reservoir is the only zone, which is the potential for economic interest because it contains storage space for fluid (hydrocarbon or water) to accumulate. A good reservoir rock must be a good porous, permeable and contains hydrocarbon as well [17]. In this study, reservoir rock was identified using the interpretation of the available log data. The gamma ray log was used in the identification of reservoir rock based on the fact that the sandstone reservoir exhibits very low radioactivity because of the low content of radioactive elements. Resistivity logs were also used in the sense that reservoir zones exhibit relatively higher resistivity values than non-reservoir zones. Based on neutron and density logs, reservoir rock was also marked by the presence of neutron-density crossover [1, $16]$.

\subsubsection{Fluid identification}

It is very important to identify the interval zone and the type of fluid in the reservoir rock, because reservoirs may contain hydrocarbon (oil and gas), non-hydrocarbon fluid (water), or both. For a reservoir to contain hydrocarbons, so the zone should be porous with resistivity values higher than those of water-bearing zones [18]. In this study, the resistivity log and neutron-density log were used to identify hydrocarbon and non-hydrocarbon-bearing intervals. Hydrocarbons are poor conductors than water and hence show higher resistivity than water-bearing intervals. Based on neutron and density crossover, the gas zone is expected to show a wider negative separation due to low density and low hydrogen index of gas, while the oil zone is also expected to show relatively low negative separation because of relatively high density and hydrogen index compared to gas. A very low separation also was observed in the water zone due to higher density and higher hydrogen index in water.

\subsubsection{Volume of shale (Vsh) calculation}

Calculation of shale volume is crucial because it helps to calculate formation porosity, fluid content, and overall rock quality. In this study, the volume of shale was estimated using a gamma ray logs method as the following equation [19]:

$\mathrm{IGR}=(\mathrm{GR} \log -\mathrm{GR} \min ) /(\mathrm{GR} \max -\mathrm{GR} \min )$

where IGR = Gamma ray Index, GRlog = gamma ray reading of the formation, $\mathrm{GRmin}=$ minimum gamma ray, maximum density log reading, IGR=Vsh in the linear model.

\subsubsection{Net to gross ratio $(h / H)$}

It is very important to determine net pay thickness to calculate original hydrocarbon in place. NTG is the ratio of the thickness of sand bearing hydrocarbon to the total thickness of sand formation [16]. It shows the volume of shale present in the reservoir. Net reservoir thickness $(h)$ can be calculated by using the following formula:

$h=H-h_{\text {shale }}$

where $H=$ The gross reservoir thickness, $h_{\text {shale }}=$ The thicknesses of the shale and Net/Gross $=h / H$.

\subsubsection{Porosity estimation}

Porosity is a very important parameter for the characterization of the reservoir rock as it is used to describe the amount of open space filled with fluid (hydrocarbon or water). In this study, total porosity and effective porosity were calculated as the following:

\section{A. Total porosity calculation}

By the combination of neutron-density logs, the total porosity within reservoirs interval was determined. The equation to compute the total porosity from neutron and density logs that may be expressed as:

$\Phi_{\text {tot }}=\left(\Phi_{\mathrm{N}}+\Phi_{\mathrm{D}}\right) / 2$

where $\Phi_{\mathrm{N}=}$ Neutron porosity, $\Phi_{\mathrm{D}=}$ Density porosity, which is calculated from this equation [20]:

$\Phi_{\mathrm{D}}=(\rho m a-\rho b) /(\rho m a-\rho f)[18]$

where $\rho b$ : bulk density which includes both fluid and rock (read directly from the log), of: density of the saturating fluid, pma: density of the rock matrix, $\varphi$ : porosity.

According to Baker (21), the criteria for classifying porosity is as follows: $\varnothing<0.05=$ Negligible; $0.05<\varnothing<0.1=$ Poor; $0.1<\varnothing<0.15=$ Fair $; \quad 0.15<\varnothing<0.25=$ Good; $0.25<\varnothing<0.30=$ Very good, $\varnothing>0.30=$ Excellent [21].

B. Determination of effective porosity 
The effective porosity is usually based on an adjustment of total porosity by means of estimated shale volume. The equation to compute effective porosity may be expressed as [22]:

$\emptyset_{\text {eff }}=\emptyset_{\mathrm{T}}-[\emptyset \mathrm{sh} * \mathrm{Vsh}]$

where $\varnothing$ eff $=$ effective porosity, $\varnothing_{\mathrm{T}}=$ total porosity, $\varnothing \mathrm{sh}=$ porosity reading in a shale zone, $\mathrm{Vsh}=$ Shale volume.

\subsubsection{Water saturation calculation}

Water saturation can be defined as the ratio of water volume to pore volume. It is calculated by porosity and resistivity logs. Determining water saturation is crucial because hydrocarbon saturation can be calculated from water saturation. In this study, Archie's model is used to calculate the water saturation of the reservoir rocks. To calculate water saturation from Archie's model, the following equation was used [23]:

$\mathrm{Sw}=(a * \mathrm{Rw}) /\left(\mathrm{Rt} * \varphi^{m)}\right)^{1 / n}$

where $\mathrm{Sw}=$ water saturation of the uninvaded zone, $a=$ tortuosity exponent, $n=$ saturation exponent, $\mathrm{Rw}=$ formation water resistivity at formation temperature, $\varphi=$ porosity, $m=$ cementation exponent, $\mathrm{Rt}=$ true formation resistivity.

\subsubsection{Hydrocarbon saturation}

Hydrocarbon saturation (Sh) is the percentage of pore volume in a formation occupied by hydrocarbon. In this study, the hydrocarbon saturation was determined by subtracting the value of water saturation from $100 \%$. Hydrocarbon saturation (uninvaded zone) percentage $\mathrm{Sh}$ is given as

$\mathrm{Sh}=(100-\mathrm{Sw}) \%$

\subsubsection{Hydrocarbon movability index calculation}

The Sw/Sxo value is equal or greater than 1.0 indicates that hydrocarbon is not moveable if the value is less than 0.7 indicate a moveable hydrocarbon condition [19]. Archie's formula has been used for the calculation of the hydrocarbon movability index. The hydrocarbon movability index is a ratio of the uninvaded zone and flushed zone which estimated by the following equation:

$\mathrm{HC}_{\text {movindex }}=\mathrm{SW} / \mathrm{Sox}$

where Sox = water saturation of the flushed zone, which is calculated from this equation $\left(S \times 0^{n}=\left(a * R_{m f}\right) /\left(\varphi^{m *} R_{x o}\right)\right)$ [23], $a=$ tortuosity exponent, $n=$ saturation exponent, $\mathrm{Rmf}=$ mud filtrate resistivity at formation temperature, $\varphi=$ porosity, $m=$ cementation exponent, Rxo = resistivity of the flushed zone.

\subsubsection{Net pay}

Net pay thickness is the most important factor to calculate hydrocarbon in place calculations because it affects reservoir management and reservoir productivity. Table 3 shows the applied cutoffs in this study.

\section{Results}

\subsection{Qualitative analysis}

\subsubsection{Lithology and potential reservoir identification}

The petrophysical analysis of well logs and according to the low gamma ray response, photoelectric effect values and neutron and density crossover, we recognize the main lithology of Al Baraka wells, which consist of three types of lithology: sand, shale and siltstone. Generally, the neutron-density logs combination and resistivity logs (MSFL and LLD) were used for the identification and characterization of various fluids in the reservoir zone. After well log interpretation and eliminate uninterested zones (high gamma ray and low deep resistivity). There are two main permeable interesting zones identified, One for AB-4 well named (S-E) and other for AB-14 well named (S-D) Figs. 6 and 9. These zones were characterized by the low gamma ray response, relatively high porosity, neutron-density crossover, and high resistivity value Figs. 12 and 13. The photoelectric effect values in Tables 2 and 4 and neutrondensity response show the dominant reservoir lithology is from shaley sandstone to sandstone. Also, the generated cross-plots indicate that the main lithology is sandstone
Table 3 The applied cutoffs for net pay calculations

\begin{tabular}{llll}
\hline Categories & Vsh & Vsh and porosity & $\begin{array}{l}\text { Vsh, porosity and } \\
\text { water saturation }\end{array}$ \\
\hline Cutoff equation & $0 \% \leq$ Vsh $\leq 45 \%$ & $10 \% \leq \varnothing>50 \%$ & $0 \% \leq \mathrm{Sw} \leq 60 \%$ \\
& & $0 \% \leq \mathrm{Vsh} \leq 45 \%$ & $10 \% \leq \varnothing>50 \%$ \\
Zone name after the cutoff & Net sand & Net reservoir & $0 \% \leq \mathrm{Vsh} \leq 45 \%$ \\
& & & Pay zone
\end{tabular}




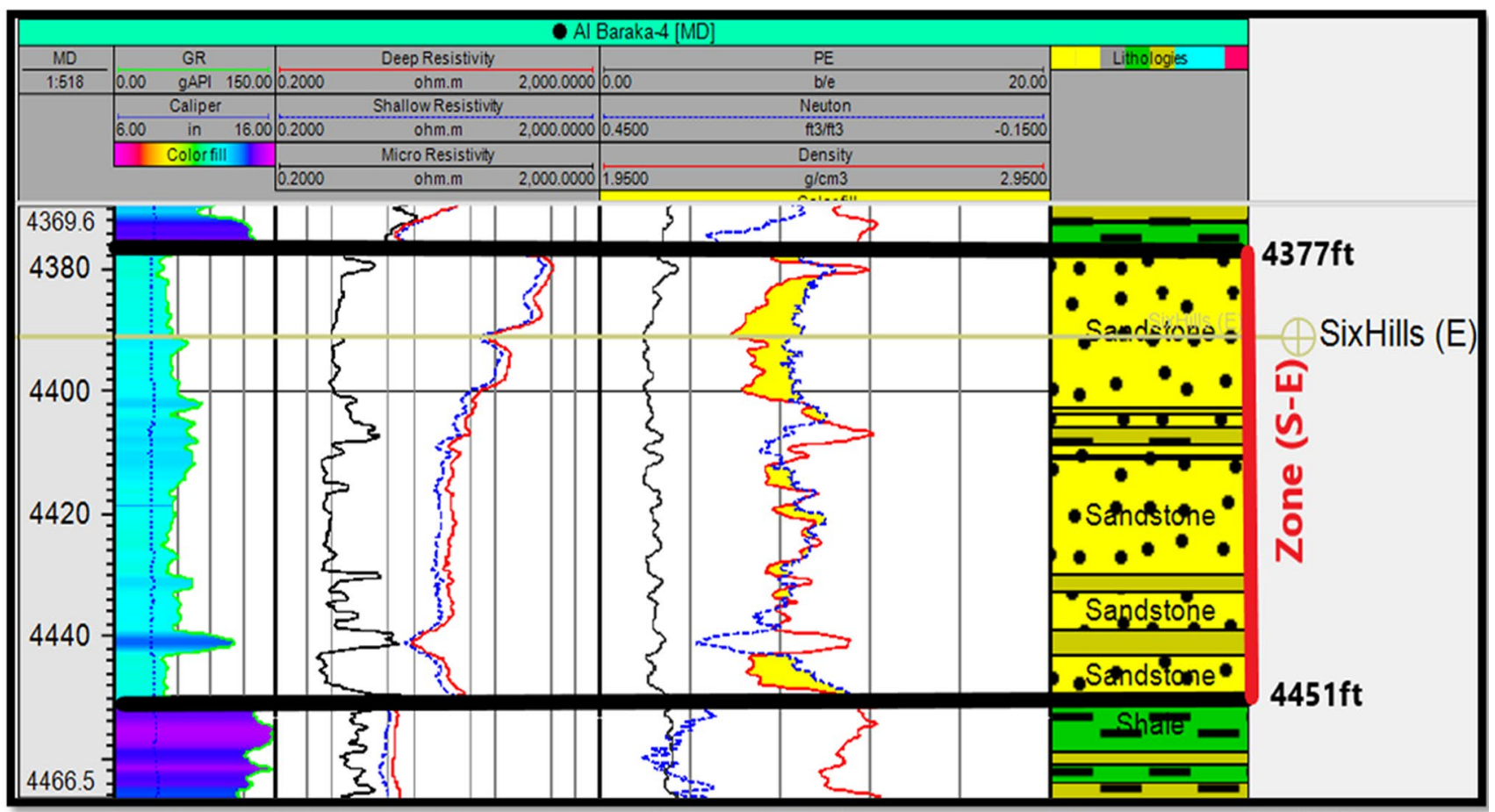

Fig. 6 The interval depth with the Composite log response and lithology interpretation of the hydrocarbon-bearing zone (S-E) in Al Baraka-4 well

Table 4 Summary of two sandstone main reservoir zones identified from well logs data

\begin{tabular}{|c|c|c|c|c|c|c|c|}
\hline Well name & $\begin{array}{l}\text { Main reser- } \\
\text { voir internal } \\
(\mathrm{ft})\end{array}$ & $\begin{array}{l}\text { Type of reservoir } \\
\text { lithology }\end{array}$ & $\begin{array}{l}\text { Type of hydrocar- } \\
\text { bons }\end{array}$ & Zone name & Thickness (ft) & Formation name & $\begin{array}{l}\text { Photoelectric } \\
\text { effect value range } \\
\text { (b/e) }\end{array}$ \\
\hline Al Baraka-4 & $4377-4451$ & Shaley Sandstone & Oil & S-E & 74 & Six Hills Fm & $1.89-3.84$ \\
\hline Al Baraka-14 & $4962-4973$ & Sandstone & & S-D & 10 & & $1.78-2.95$ \\
\hline
\end{tabular}

in the S-D zone Figs. 10 and 11 and shaley sandstone in S-E zone Figs. 7 and 8. The reason for categorizing the two sand units as two different potential reservoir zones were based on eliminating thick shale beds between reservoirs and low value of deep resistivity so as to reduce the effect of both increasing shale volume and high-water saturation when computing other petrophysical parameters.

\subsection{Quantitative analysis}

The two reservoir zones have been selected across Al Baraka wells interpretations lie at depth interval from 4377 to $4451 \mathrm{ft}$ for S-E zone and from 4962 to $4973 \mathrm{ft}$ for S-D zone with thicknesses ranging from 74 to $10 \mathrm{ft}$, respectively, Figs. 6 and 9. The two selected zones were analyzed quantitatively to estimate the values of shale volume, porosity, and water saturation, net pay by using empirical formulas as described in the methodology part. The average total and effective porosity results of the delineated in S-E and S-D reservoir zones range from 14.3 to $17.1 \%$ and 18.2 to $20.2 \%$, respectively. The average shale volume estimated from the gamma ray log was found to be $0.20(\mathrm{v} / \mathrm{v})$ and $0.085(\mathrm{v} / \mathrm{v})$ for S-E and $S-D$, respectively. The calculated value of average water saturation from the arhi equation is $57.5 \%$ for S-E and $36.4 \%$ for S-D. On the other hand, we used the average water saturation values to estimate the value of hydrocarbon saturation, which is ranged from $42.5 \%$ for S-E and $63.6 \%$ for the S-D zone; these hydrocarbons have movability index low than 0.7 and is between 0.58 and 0.61. After applying cutoff in Table 3, the net pay thickness range from $8 \mathrm{ft}$ for the $S$-D zone to $24 \mathrm{ft}$ for the S-E zone. All petrophysical parameters estimated for the hydrocarbon-bearing zones and net pay are shown in Tables 5 and 6 and Figs. 12 and 13. 


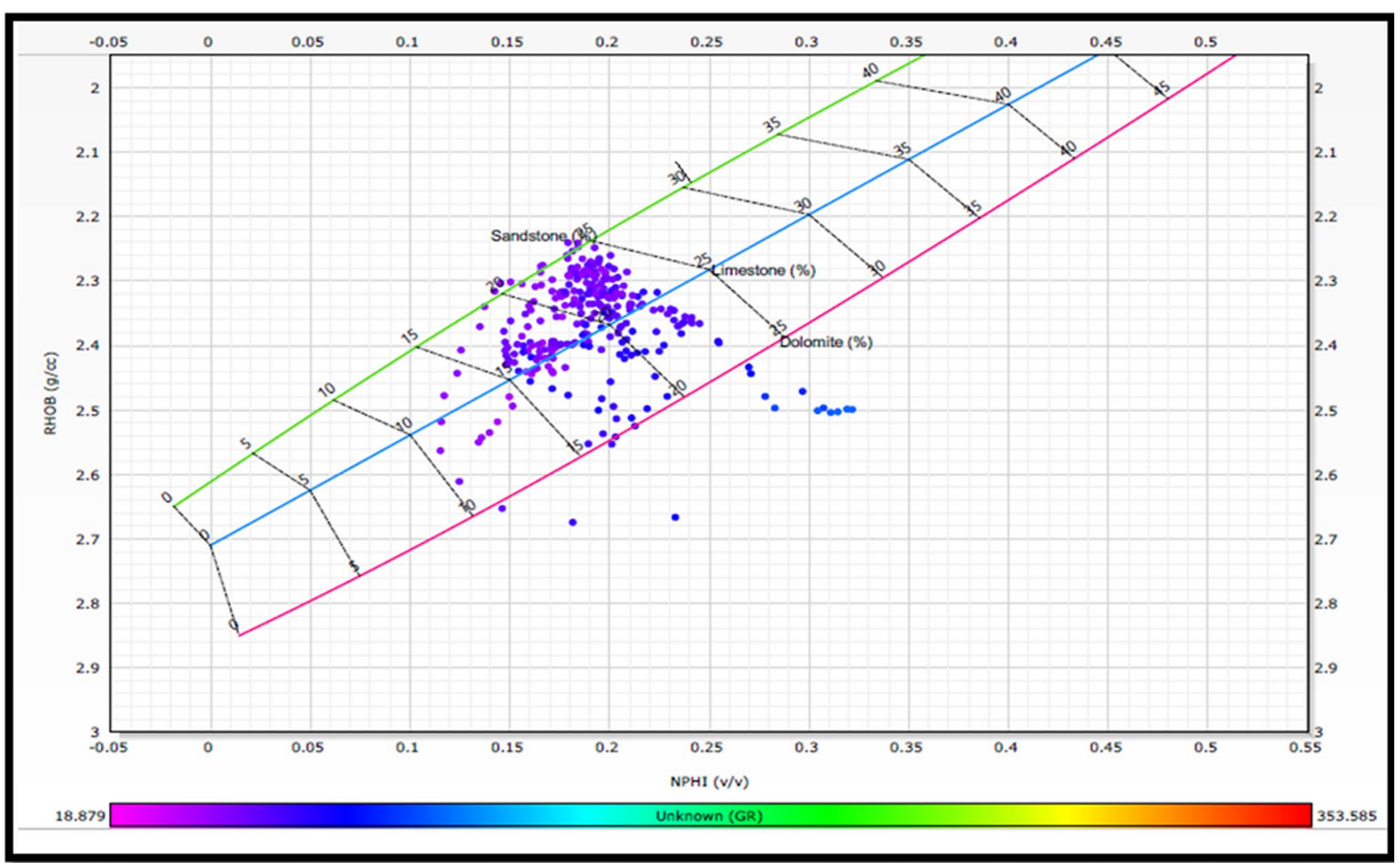

Fig. 7 Density-neutron-gamma ray cross-plot of the main reservoir (S-E zone) in Al Baraka - 4 well

\section{Discussions}

\subsection{Petrophysical parameters assessment from qualitative analysis}

The well logs analysis of Al Baraka wells indicates that the subsurface lithostratigraphy consists of three types of lithology, which are sand and shale interbedding. Based on the interpretation of wireline logs, there are two permeable interesting zones considered as the main potential reservoirs identified and evaluated, both in Six Hills Fm of lower cretaceous, One for AB-4 well named (S-E) and other for AB-14 well named (S-D). Neutron-density and density-photoelectric effect cross-plots strongly show the dominant reservoir lithology is Shaley sandstone to sandstone. The location shale formation related to the identified reservoirs could thus be potential source rock or act as a seal rock.

\subsection{Petrophysical parameters assessment from quantitative analysis}

The two reservoir zones have been selected across $\mathrm{Al}$ Baraka wells interpretations lie at depth interval from 4377 to $4973 \mathrm{ft}$ with the high net to gross value ranging from 0.94 to 0.95 Table 5. Al Baraka-4 well cross-plots in Figs. 7 and 8 shows that the porosity is ranging from 12 to $25 \%$ and also show that gamma ray value mostly is low; so, this proves the S-E reservoir zone contains mostly highly porous sandstone, but in Al Barka-14 well cross-plots in Figs. 10 and 11 show that the porosity is ranging from 17 to $22 \%$ and also show that gamma ray value is low; so, this proves the S-D reservoir zone contains mostly porous sandstone. The average total porosity results of the delineated in S-E and S-D reservoir zones ranging from 18.2 to $20.2 \%$, respectively, which indicates that the reservoir quality ranges from moderate to good porosity. The average shale volume is 0.20 $(\mathrm{v} / \mathrm{v})$ and $0.085(\mathrm{v} / \mathrm{v})$ for S-E and S-D, respectively, that reveal to the low distribution of low permeable shale content in the reservoir zones. The estimated value of average water saturation is $57.5 \%$ for S-E and $36.4 \%$ for $S-D$, which indicates that the proportion of void space occupied by water is low consequently with high hydrocarbon saturation ( $42.5 \%$ for S-E and $63.6 \%$ for S-D zone). The net pay zone thickness ranges from 8 to $24 \mathrm{ft}$ and characterized by high hydrocarbon saturation, good porosity, very low shale volume that leading to high hydrocarbon production Tables 5 and 6 . Related to the values of the mobility index, the hydrocarbon-bearing 


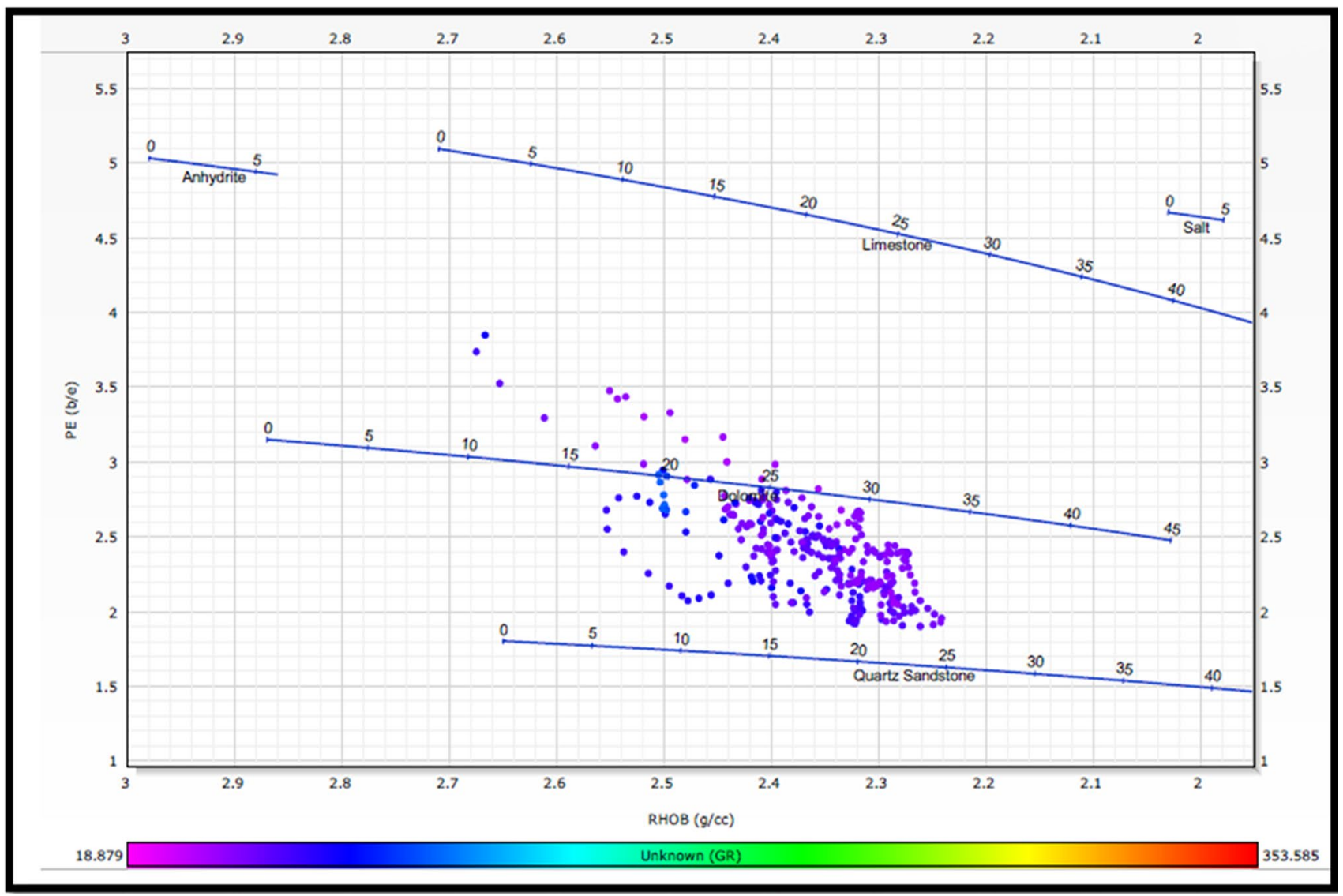

Fig. 8 Density-photoelectric effect-gamma ray cross-plot of the main reservoir (S-E zone) in Al Baraka-4 well

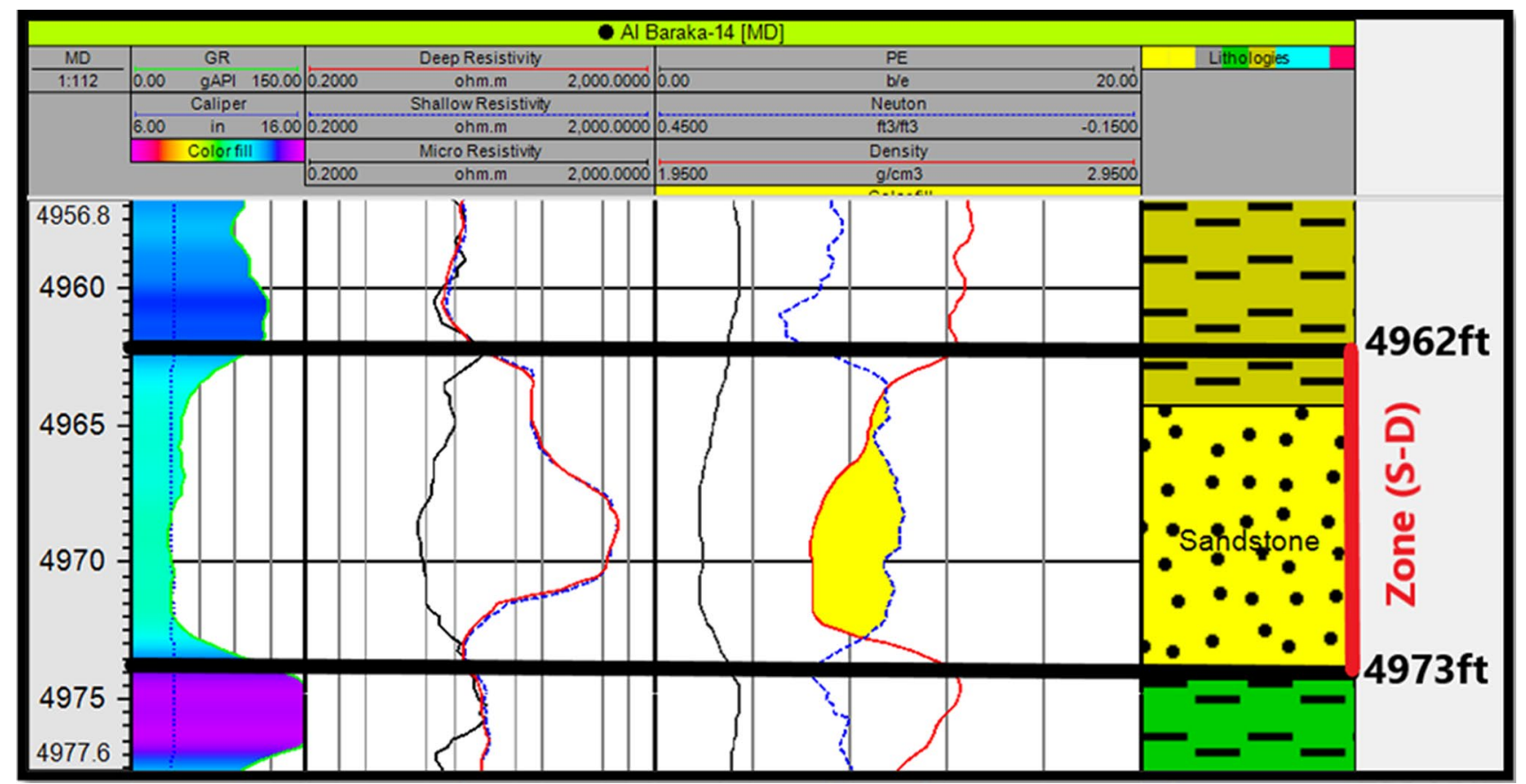

Fig. 9 The interval depth with the Composite log response and lithology interpretation of the hydrocarbon-bearing zone (S-D) in Al Baraka-14 well

SN Applied Sciences 


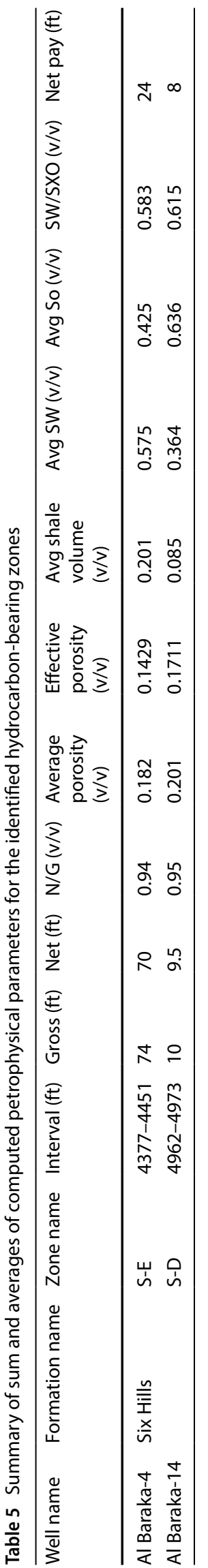

Table 6 Summary of averages computed petrophysical parameters for the net pay of two identified hydrocarbon-bearing zones

\begin{tabular}{|c|c|c|c|c|c|}
\hline $\begin{array}{l}\text { Zone } \\
\text { name }\end{array}$ & $\begin{array}{l}\text { Net pay } \\
(\mathrm{ft})\end{array}$ & $\begin{array}{l}\text { Av_Shale } \\
\text { volume } \\
(\mathrm{v} / \mathrm{v})\end{array}$ & $\begin{array}{l}\text { Av_ } \\
\text { Porosity } \\
\text { (v/v) }\end{array}$ & $\begin{array}{l}A v_{-} \\
\text {Water } \\
\text { satura- } \\
\text { tion }(v / v)\end{array}$ & $\begin{array}{l}\text { Av_Hyd- } \\
\text { robon } \\
\text { saturation } \\
(\mathrm{v} / \mathrm{v})\end{array}$ \\
\hline S-D & 24 & 0.189 & 0.19 & 0.281 & 0.719 \\
\hline S-E & 8 & 0.083 & 0.199 & 0.279 & 0.721 \\
\hline
\end{tabular}

reservoir is distinguished by high movability as shown in Table 5 and Figs. 12 and 13.

\section{Conclusion}

Generally, by considering all parameters such as permeable zone identify, reservoir thickness, shale volume, porosity, water saturation, net pay thickness and hydrocarbon saturation from the log analysis performed in this study, there are two hydrocarbon-bearing reservoirs present in Six Hills Fm of the lower cretaceous age, which named as S-E zone in AB-4 well and S-D zone in AB-14 well with varying thicknesses identified and evaluated. Different cross-plots are constructed (neutron-density and photoelectric effect-density cross-plots) to display the reservoir lithology. These cross-plots with also well log analysis reflect that the lithology in S-E and S-D zone varies in the available wells from shaley sandstone to sandstone. The hydrocarbon zones were proven by petrophysical analyses that show high porosity, low water saturation, low shale volume, and high net-to-gross ratio. Based on petrophysical parameters obtained, the two selected reservoir zones have moderate to good porosity of $18.2 \%$ to $20.1 \%$, the low effect of shale distribution ( $20 \%$ to $8.5 \%$ ), whereas average hydrocarbon saturation ranged from 42 to $57 \%$ with high movability. The study reveals that the hydrocarbon-bearing reservoir is the potential for commercial oil production and accumulation, essential oil. Below and above the oil-bearing reservoirs, there is a thick shale bed which is acted as potential source rock or as a seal rock. 


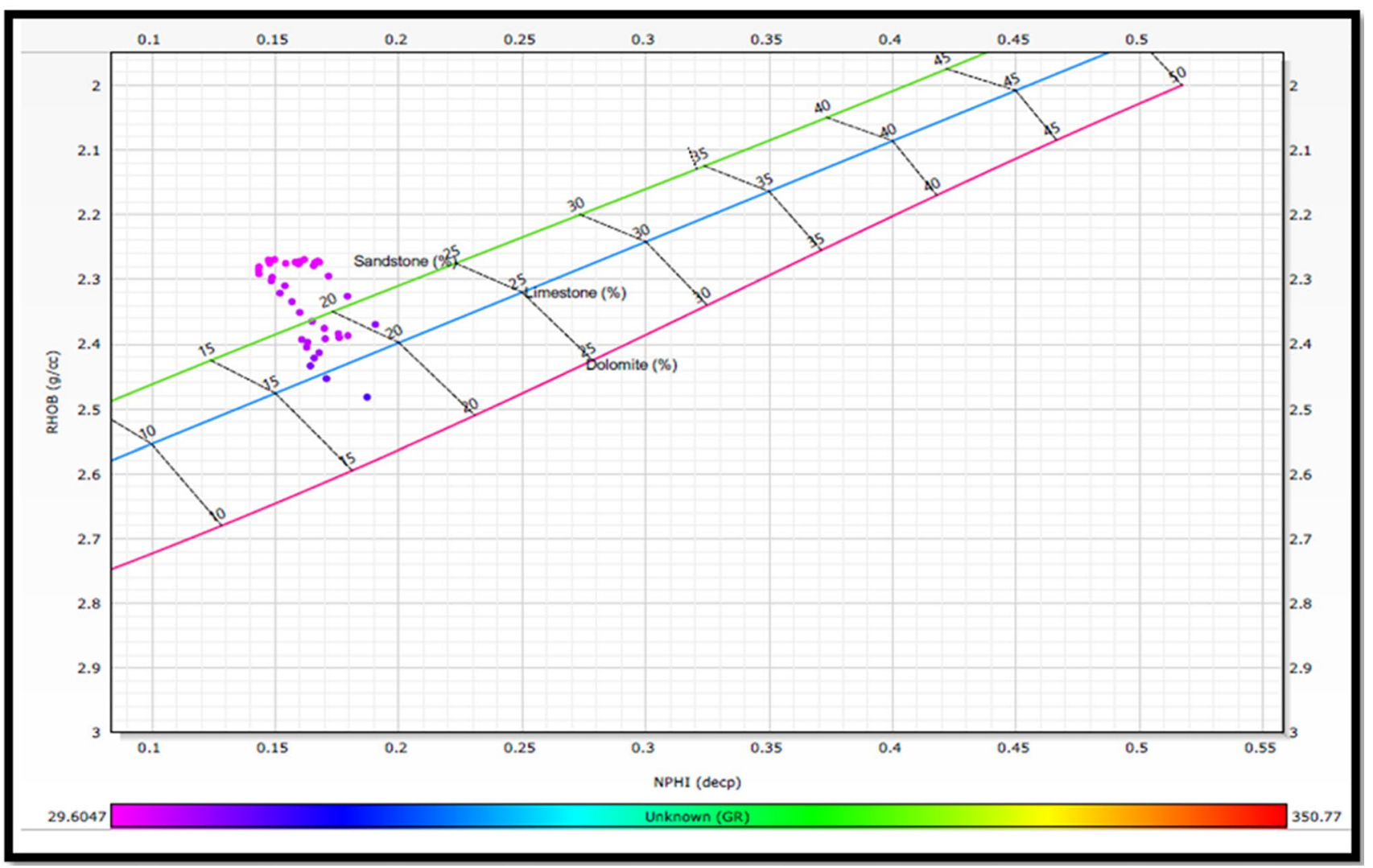

Fig. 10 Density-neutron-gamma ray cross-plot of the main reservoir (S-D zone) in Al Baraka -14 well 


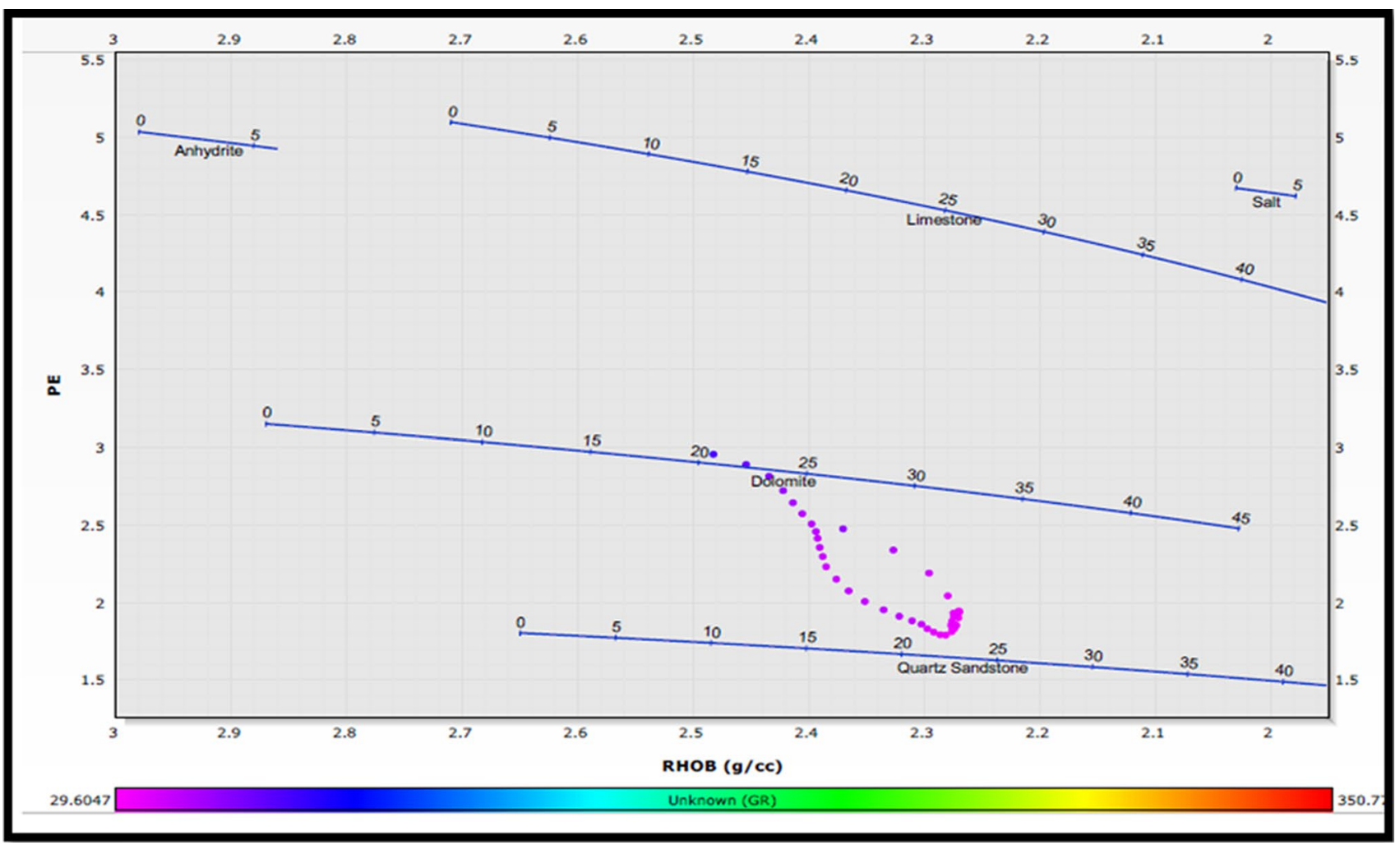

Fig. 11 Density-photoelectric effect-gamma ray cross-plot of the main reservoir (S-D zone) in Al Baraka-14 well

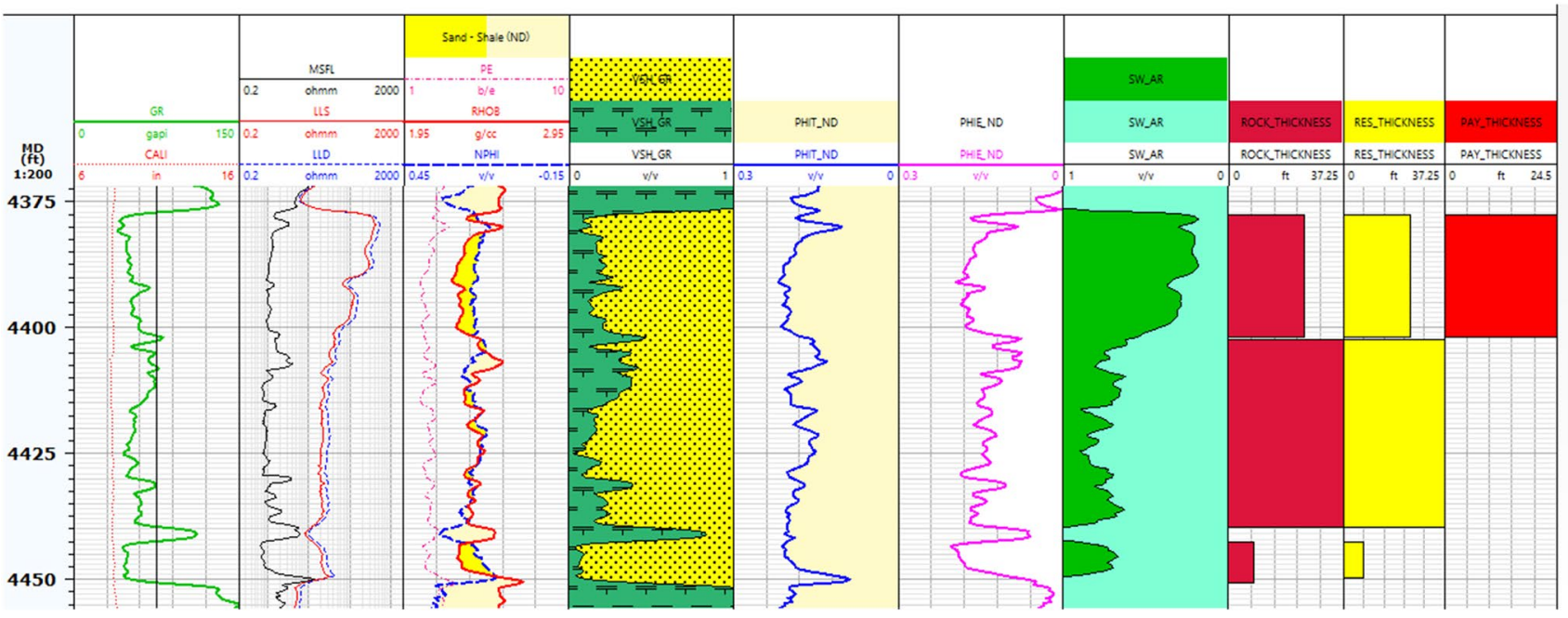

Fig. 12 Digitizing of calculated petrophysical parameters of the main reservoir (S-E zone) along the Al Baraka-4 well 


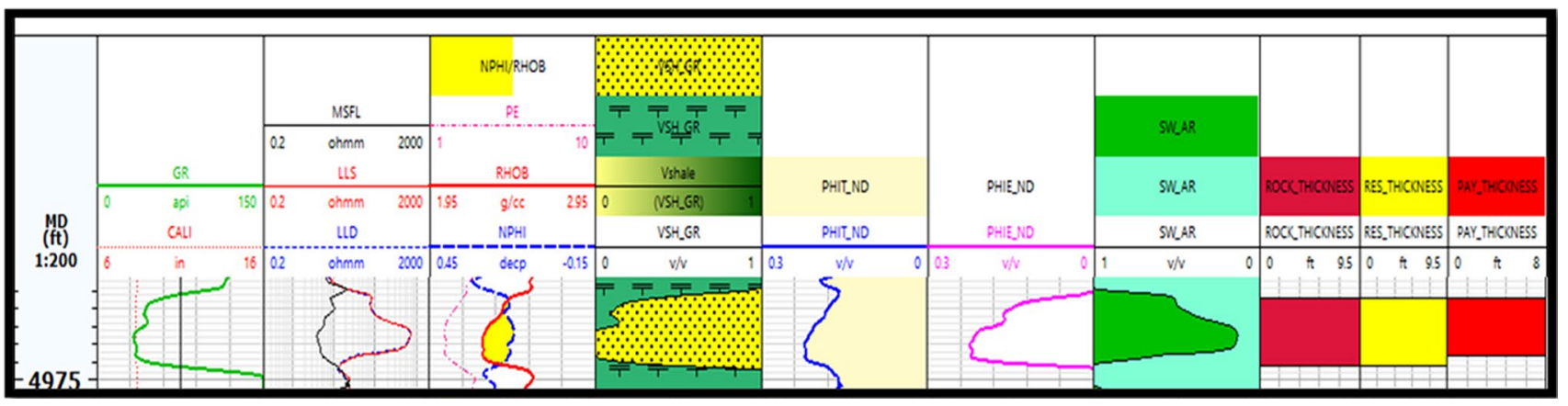

Fig. 13 Digitizing of calculated petrophysical parameters of the main reservoir (S-D zone) along Al Baraka-14 well

Acknowledgements The authors would like to express his gradual thanks to Ganoub El Wadi Petroleum Holding Company for providing the needed data.

\section{Compliance with ethical standards}

Conflict of interest On behalf of all authors, the corresponding author states that there is no conflict of interest.

\section{References}

1. Lyaka AL, Mulibo GD (2018) Petrophysical analysis of the Mpapai well logs in the east Pande exploration block, southern coast of Tanzania: geological implication on the hydrocarbon potential. Open J Geol 8:781-802

2. Helander DP (1983) Fundamentals of formation evaluation. Oil \& Gas Consultants International

3. Abdelhady A, Darwish M, El-Araby A, Hassouba A (2016) Evaluation of Neocomian shale source rock in Komombo basin, Upper Egypt. Int J Innov Sci. Eng Technol 3:376-382

4. Othman A, Ewida H, Fathi MA, Embaby M (2015) Prediction of petrophysical parameters applying multi attribute analysis and probabilistic neural network techniques of seismic data for Komombo Basin, Upper Egypt. Int J Innov Sci Eng Technol 2:638-653

5. Selim S (2016) A new tectono-sedimentary model for Cretaceous mixed nonmarine-marine oil-prone Komombo Rift, South Egypt. Int J Earth Sci 105:1387-1415

6. Ali M, Darwish M, Abdelhady A, Essa M (2017) Structural and Lithostratigraphic evolution of Al Baraka Oil field, Komombo Basin, Upper Egypt as deduce from 2D seismic lines and well logging data. J Basic Environ Sci 2:31-51

7. Dolson JC, Shann MV, Hammouda H, Rashed R, Matbouly S (1999) The petroleum potential of Egypt. AAPG Bull. https:// doi.org/10.1306/E4FD46A7-1732-11D7-8645000102C1865D

8. Ali M, Darwish M, Essa MA, Abdelhady A (2018) 2D seismic interpretation and characterization of the Hauterivian-Early Barremian source rock in Al Baraka oil field, Komombo Basin, Upper Egypt. J Afr Earth Sci 139:113-119

9. Abu El Ella N (2011) Biostratigraphic studies for the Al Baraka Oil Field, Upper Egypt. (EREX), Cairo Unpublished Inernal Report
10. Nagati M (1986) Possible Mesozoic rifts in Upper Egypt: an analogy with the geology of Yemen-Somalia rift basins. Proceeding of the 8th petroleum exploration conference, vol 2, pp 205-231

11. Said SM, Sakran S (2020) Structural analysis and tectonic evolution of the Komombo basin, south Egypt; an example of interior Cretaceous rift. J Afr Earth Sci 162:103719

12. Said R (1990) The geology of Egypt: balkema. Rotterdam, Brookfield, p 734

13. Ali M, Abdelhady A, Abdelmaksoud A, Darwish M, Essa MA (2020) 3D static modeling and petrographic aspects of the Albian/Cenomanian Reservoir, Komombo Basin, Upper Egypt. Nat Resour Res 2:1259-1281

14. Macgregor DS, Moody RT (1998) Mesozoic and Cenozoic petroleum systems of North Africa. Geolog Soc Lond Spec Publ 132:201-216

15. Amigun JO, Odole OA (2013) Petrophysical properties evaluation for reservoir characterisation of Seyi oil field (Niger-Delta). Int J Innov Appl Stud 3:756-773

16. Nwankwo C, Anyanwu J, Ugwu S (2014) Integration of seismic and well log data for 17 petrophysical modeling of sandstone hydrocarbon reservoir in Niger Delta. 13:186-199

17. Ellis DV, Singer JM (2007) Well logging for earth scientists. Springer, Dordrecht, $\mathrm{p} 692$

18. Crain E (2016) Visual analysis rule for water saturation, Petrophysical Handout

19. Islam A, Habib M, Islam M, Mita M (2013) Interpretation of wireline log data for reservoir characterization of the Rashidpur Gas Field, Bengal Basin. Bangladesh 1:47-54

20. Dolan P (1990) Pakistan: a history of petroleum exploration and future potential. Geolog Soc Lond Spec Publ 50:503-524

21. Baker H (1992) Advanced wireline and MWD procedures manual

22. Atlas D (1979) Log interpretation charts: Dresser Industries. nc., p 107

23. Archie GE (1942) The electrical resistivity log as an aid in determining some reservoir characteristics. Trans AIME 146:54-62

Publisher's Note Springer Nature remains neutral with regard to jurisdictional claims in published maps and institutional affiliations. 